\title{
Sea Transportation System Policy
}

\author{
Ma Junyu ${ }^{1}$, Ong Argo Victoria ${ }^{2}$, and Devina Arifani ${ }^{3}$ \\ ${ }^{1}$ Gentle Company, Islamic College Zhengzhou, China \\ ${ }^{2}$ International Researcher of International Islamic University Malaysia (IIUM) \\ ${ }^{3}$ Secretary of AEJI Institute for Journal Indexing Malaysia-Indonesia
}

\section{Abstract}

The government policy regarding sea tolls is to navigate goods transportation, guarantee the availability of goods, reduce price disparities, and ensure the continuity of goods transportation services to underdeveloped, remote, and border areas. Maritime transportation development policies are directed at increasing the role of the national shipping fleet, both domestic and export-import by applying the cabotage principle; eliminating illegal levies at ports through improved coordination for all agencies related to the loading and unloading process and meeting international shipping standards and the implementation of International Ship and Port Security; restructuring the shipping legislation and its implementation, as well as institutions in

Corresponding Author:

Ma Junyu

313395733@gmail.com

Published: 12 January 2021

Publishing services provided by Knowledge E

(c) Ma Junyu et al. This article is distributed under the terms of the Creative Commons

Attribution License, which permits unrestricted use and redistribution provided that the original author and source are credited.

Selection and Peer-review under the responsibility of the IWPOSPA Conference Committee.

\section{G OPEN ACCESS} the marine transportation sub-sector in order to create conditions that are capable of attracting private interest in the development of marine transportation infrastructure. Sea transportation policy is defined as the lifeblood of increasing national development for the smooth flow of people, goods and information. This policy supports the optimal allocation of economic resources, so that sea transportation services are fairly evenly available and affordable for the people's purchasing power.

Keywords: policy, sea transportation system, national development.

\section{Intorduction}

Transportation is a very important field of activity in the life of the Indonesian people and even the world. The importance of transportation for Indonesians is caused by several factors, including the geographical condition of Indonesia which consists of thousands of small and large islands (archipelago); waters consisting of a large part of the sea; rivers and lakes that allow transportation to be carried out by land and water and air to reach all parts of Indonesia. Thus, Indonesia is the largest archipelagic country in the world, with a sea area covering 2/3 of its total territorial area (Herdiyeni, Yeni., Mahmud Zuhud, Ervizal Amir, \& Rudi Heryanto. (2014). Development of Mangrove Database for Biodiversity Informatics of IPB Biopharmaca. Jurnal Ilmu Pertanian Indonesia 19 (3): 197-203). 
Another thing that is no less important for the need for transportation is the need for comfort, security, and smooth transportation that supports the implementation of development in the form of distribution of development needs, equitable development, and distribution of development results in various sectors throughout the country, for example the industrial sector, trade., tourism, and education. (Hobbs, FD. 2008. Perencanaan dan Teknik Lalu Lintas. Yogyakarta: Gajah Mada University Press. p.22)

In general, transportation plays an important role in two ways, namely economic development and non-economic development. Economic objectives include increasing national income, developing national industry and creating and maintaining employment opportunities for the community. In line with these economic goals. (Ilham, Chairul Insani, \& Wawan Darwan. (2015). Keseimbangan antara Pendapatan dan Biaya Operasional Kapal Penyeberangan Lintas Jangkar- Kalianget. Jurnal Manajemen Transportasi \& Logistik 2 (1); 26-35) absolutely necessary. Considering the important and strategic role of road traffic and transportation in controlling the lives of many people, the interests of the general public as users of transportation services need to get priority and optimal services from both the government and transportation service providers (Hobbs, FD. (2008). Perencanaan dan Rekayasa Lalu Lintas. Yogyakarta: Gajah Mada University Press. p.29).

Regarding the past administration and sea transportation, it also needs to be carried out on an ongoing basis, and improved so that it has a wider reach and services to the community. By continuing to pay attention to the public interest, community capacity, environmental sustainability, and public order in the management of sea traffic and transportation, at the same time realizing a reliable and integrated national transportation system. With transportation, the distribution of goods and production products can be carried out evenly throughout the region, so that regional income can increase and open up isolated areas, as well as increase income for the region and the country at a macro level (Ilham, Chairul Insani \& Wawan Darwan. (2015). Balance between Revenue and Operating Costs for the Cross Anchor-Kalianget Crossing Vessel. Journal of Transportation \& Logistics Management 2 (1); 26-35).

Whatever it is must have problems, as well as the marine transportation system. The problem of slow procurement and repair of marine transportation facilities and infrastructure or very limited availability of infrastructure, delays and water pollution, air pollution are some of the many problems that 6,000 islands in the archipelago. Air transportation is expensive and limited, relying $100 \%$ on land transportation is also not possible, because almost Indonesia can connect the islands with existing bridges. 
In addition, scientifically, with a very large carrying capacity, sea transportation is the cheapest, most effective and efficient mode of transportation of all the available modes. With this need, it is very clear where the importance of maritime development is in the government's flagship program. Even the New Order government's "Pelita" program which emphasized Indonesia as an agrarian country headed for an industrialized country, in fact also touched on the fact that Indonesia is a maritime country.

\section{Research Methods}

In this research, library research or library research methods will be used. Regarding this kind of research, it is usually called "Legal Research". Legal research of this kind does not recognize field research because what is being studied is legal materials, so it can be said that it is library based, focusing on reading and analysis and analysis of the primary and secondry materials. This method is pursued by a system of reviewing a number of related statutory archives, books, books and other scientific works on the internet that can be used as a reference source for this paper. Done by collecting data based on data related to research problems.

Based on the research objectives to be achieved, it begins with examining all available data from various data sources, namely documentation and data obtained from literature. By conducting data reduction, namely data obtained from literature and summarized by selecting main things and arranged more systematically so that they are easy to control.

Legal research is a scientific activity, which is based on methods, systematics, and certain thoughts, which aim to study one or more legal phenomena by analyzing them. In addition, research also carries out an in-depth examination of these legal facts and then seeks a solution to the problems that arise in the symptoms concerned.

This study aims to analyze marine transportation policies in realizing modern sea highway transportation and enhancing development. This study aims to analyze the results of research as a whole and the effectiveness of the overall system policy formulation (think description).sea transportation in the context of realizing modern sea highway transportation and increasing development in Indonesia. This research was conducted at the Ministry of Transportation, especially at the Directorate General of Maritime Transportation, the National Development Planning Agency (Bappenas), and PT Pelayaran Nasional Indonesia (PT Pelni). The research method used is descriptivequalitative. This method emphasizes the indept interview, the triangulation process, 
focus group discussion (FGD), the emic approach, and ethics and verstahen (Creswell, 2002).

In this study, the determination of informants was carried out purposively or the selection of informants was carried out deliberately with certain criteria according to their basic competency capacities. In this qualitative research, a researcher is also the main research instrument. Processing and analysis of data through a process of triangulation (triangulation) and Focus Group Discussion (FGD), so as to produce a complete and comprehensive research (think description).

\section{Result and Discussion}

The marine highway transportation system policy in Indonesia is part of the public policy process and this stage is the most crucial, because the implementation and evaluation of policies as the next stage can only be carried out effectively if the policy formulation stage has been completed properly. In addition, the failure of a maritime highway transportation system policy or program in Indonesia to achieve its objectives is largely due to imperfection.

or ineffective formulation stage management. Policy formulation is the same as policy formation, namely the marine highway transportation system policy in Indonesia which is a series of actions to select various alternatives that are carried out and in it includes decision making. (Supriyanto. (2015). Public Transportasi Idaman. http://www.aipse.org/ de/artikel/4-public-transportation-ideal.html. accessed on 18 oktober, 2020)

The effectiveness of the state (public) policy making / formulation process in the marine transportation sector can be viewed in 2 (two) types of activities. The first activity, is to decide in general what to do, or in other words the formulation of a sea highway transportation system that is directed at obtaining agreement on a chosen policy alternative, an approved decision is the result of the entire process. (Nugroho, Adi Lanugranto. (2008). Layanan Konsumen dan Transportasi. Surakarta: Muhammadiyah University of Surakarta. p. 32) The next activity is directed at how policy decisions are made, in this case a policy decision includes actions by an official or official institution or authorized to handle them, namely the Indonesian Ministry of Transportation, particularly the Directorate General of Transportation, to approve, change or reject an alternative policy that is currently being selected. Prosestriangulation among informants with authentic facts that exist in the form of related provisions, confirms that the formulation of the maritime highway transportation system policy is especially in the formulation 
of policy issues, preparation of government agendas, formulation of policy proposals, policy approval, policy implementation

Policy assessment. The formulation of policy problems, in principle, even though a particular event, situation and situation can cause one or several problems, but for it to become a public problem depends not only on its objective dimensions, but also subjectively, both by the public and by decision makers, is seen as a problem that should be solved or resolved.

The targets for marine transportation development include increasing share the national shipping fleet market for domestic sea transportation and import-export; improved port performance and efficiency; Increased adequacy and reliability of shipping navigation aids; increased role of private sector in investing in port infrastructure. Furthermore, it was explained that the direction of marine transportation development policies, among others, is to increase the role of the national shipping fleet for both domestic and export-import transportation by applying the cabotage principle; eliminating illegal levies at ports through improved coordination for all agencies involved in the loading and unloading of goods; (Haryadi, Bambang \& Bambang Riyanto, (2007). City Density in a Sustainable Transportation Development Perspective. Journal of Civil Engineering and Planning 9 (2): 89-97.)

Furthermore, restructuring the laws and regulations (revision of Law No. 21 of 1992 concerning Shipping and its implementing regulations) as well as institutions in the marine transportation sub-sector in order to create conditions that are able to attract private interest in the development of marine transportation infrastructure. Gradually hand over regional and local port assets managed by the Technical Implementation Unit/ Work Unit to the Provincial Government and Regency / City Government. The updating of the national port order refers to Sistranas. Lastly, to continue the pioneering sea transportation service. the marine transportation system policy, that the marine or maritime environment also has five interconnected military strategy dimensions, namely the economic dimension. The use of the sea as a medium of transportation,

Regarding the sea highway cargo mode, the following results are presented in indepth interviews with informants, that transportation or sea highway transportation is a field of transportation activities, including the transportation of goods which is very important in the life of the Indonesian people. The importance of cargo transportation in the marine transportation system for the people of Indonesia is caused by several factors, among others, the geographical condition of Indonesia which consists of thousands of small and large islands (archipelago), waters which consist of most of the seas, 
rivers and lakes that allow transportation to be carried out by land, water., and air to reach all parts of Indonesia.

Economic growth which is concentrated on the island of Java has resulted in inefficient and expensive sea transportation in Indonesia because there is no return cargo from areas with low economic growth. The results of observations show that in principle, this maritime highway will practically and efficiently resolve the imbalance in logistics prices that has occurred so far, because large ships connect ports accompanied by feeders from Sumatra to Papua. The eastern part of Indonesia has been bearing the burden of very expensive logistics costs due to the concentration of the economy on the island of Java. With the realization of the marine highway national program, it is hoped that it can make a big contribution, (Kadarisman, Muh., Aang Gunawan, \& Ismiyati (2015). Policy Implementation Of Land Transportation System and Its Impact Towards Social Welfare In Jakarta. Journal of Transportation \& Logistics Management 2 (1): 62-68.)

Transportation is the lifeblood of increasing national development to smoothen the flow of people, goods and information to support the optimal allocation of economic resources. For this reason, transportation services must be sufficiently available and affordable for the people's purchasing power. One of the transportation used by people in Indonesia is sea transportation. The increase in population and city area causes the number of sea transportation traffic to also increase. The traffic system is approaching saturation, so an increase in the amount of traffic has a major impact on the environment.

Transportation is a benchmark in the interaction between areas of community transformation, and it plays a very important role in supporting the development process of an inter-island area. In the field of sea transportation, the development of facilities and infrastructure, such as ports, ships, etc., has improved production and distribution services which are important and play a major role in supporting national economic growth, promoting equitable development between regions and national stability, and increasing the standard of living and welfare of the community..

The success of development is strongly influenced by the role of transportation as the lifeblood of politics, economy, socio-culture and defense and security. The transportation network system can be seen in terms of effectiveness, in terms of safety, high accessibility, integrated, sufficient capacity, orderly, smooth and fast, easy to reach, on time, comfortable, affordable, orderly, safe, low pollution and in terms of efficiency in terms of low public burden and high utility in a single transportation system network. For example, throughout 2015 the Ministry of Transportation targeted to build 163 ports. 
This development is a priority program which is completed within a year (2015). The port development is more focused on Eastern Indonesia, such as NTT, Maluku and Papua.

The advancement of transportation will lead to an increase and development of development, for example human mobility, mobility of production factors and mobility of marketed processed products. The higher the mobility is carried out, the faster the distribution movement and the shorter the time it takes to process the material and move it from a place where the material is previously less useful to a location with greater benefits. Increased productivity, because this transportation is the main motor of economic progress that is able to develop conditions under development.a developing economy will be shown by the presence of high mobility, supported by adequate and smooth transportation. Like developed countries, they have transportation that supports them in every activity they do. With good transportation, it will facilitate interaction between local residents and the outside world. Isolation is the first problem that must be addressed. (Op.cit) Transportation serves as a bridge that connects producers with consumers. Transportation and regional development have problem dimensions with a wide and complex range. Therefore, in order to understand the work patterns of transportation and accessibility, it is required to have a broad view not only in one field of scientific study. Transportation and regional development are very closely related, because in regional development one must have supportive transportation. shows that transportation can also advance the economic welfare of the community, create and increase the level of accessibility of natural resource potentials and market size. Natural resources that were previously not utilized will be affordable and can be processed. (Aminah, Siti. (2006). Transportasi Public dan Aksesibilitas Masyarakat Perkotaan. Surabaya: Universitas Airlangga. p. 33)

Transportation infrastructure acts as a tool for directing development and as an infrastructure for the movement of people and / or goods as a result of economic activity in the area. For example, a new residential area that is going to be marketed will never be interested if transportation infrastructure is not provided in that location. (lbid)

The higher the mobility carried out, the faster the distribution movement as well shorter time needed to process the material and move it from the place where the material is not useful to the location where the benefits are greater. Increased productivity, because this transportation is the main motor of economic progress. A developing economy will be demonstrated by the presence of high mobility, supported by adequate and smooth transportation. Like developed countries, they have transportation that supports them in every activity they do. (Ibid) 
With good transportation, it will facilitate interaction between local residents and the outside world. Isolation is the first problem that must be addressed. Transportation serves as a bridge that connects producers with consumers. sea toll transportation is a measure of interregional interaction. A particular region depends on other regions. Likewise, other regions have dependence on certain areas, so that they are getting closer to the desired community. Among these areas, there are certain areas that have advantages over others, so that these areas have several facilities that are able to serve the needs of the population within a wider radius, so that residents in a certain radius will come to the area to obtain the necessary needs, and so on, to a dynamic society in various aspects. The results of observations indicate that due to differences in the level of resource ownership and the limited ability of the region to support the needs of the population of an area, it has led to the exchange of goods, people and services between regions. This exchange begins with a supply and demand process. (Mutholib, A. (2013). Kajian fasilitas keselamatan kapal pada lintas penyeberangan 35 ilir-muntok. Jurnal Transportasi, 25(5), 140-146)

As a tool for the supply and demand process that needs to be delivered to other regions, transportation facilities are needed. Possible means of transportation to assist mobility in the form of public transportation. In carrying out their lives, humans use living spaces called settlements which are formed from elements of working, opportunities, circulation, housing, recreation, and other living facilities. The circulation element is the transportation and communication network that exists in settlements. Transportation system and communication includes internal and external systems. (Herdiyeni, Yeni., Mahmud Zuhud, Ervizal Amir, \& Rudi Heryanto. (2014). Development of Mangrove Database for Biodiversity Informatics of IPB Biopharmaca. Indonesian Journal of Agricultural Sciences 19 (3): 197-203)

The first type discusses the network system that exists in the residential unit itself. The second type discusses the quality and quantity of the network that connects one settlement to another within a single settlement unit. The movement of people and goods from one place to another always goes through certain paths. The place of origin and destination are connected to each other by a network (network) in space. The network can be a road network, which is part of the transportation system. (lbid)

Transportation is an important thing in a system, because without transportation, transportation between one place and another is not well realized. That the interregional interaction is reflected in the condition of transportation facilities and the flow of people, goods and services. transportation is a benchmark in the interaction between regions and has a very important role in supporting the development process of an 
area. Areas with diverse geographical conditions require integration between types of transportation in serving the needs of the community. Basically, the transportation system was developed to connect two locations for different land uses. Transportation is used to move people or goods from one place to another so that it has increased economic value.

With good transportation, it will facilitate interaction between local residents and the outside world. Isolation is the first problem that must be addressed. Transportation serves as a bridge that connects producers with consumers and eliminates the distance between the two. This distance can be expressed as a distance of time to a geographical distance. Time interval arises because goods produced today may not be used until tomorrow. (Meyer \& Miller. (2007). Urban Transportation Planning. Singapura: McGraw-Hill International. Nasution, MN. 2006. ManajemenTransportasi. Jakarta: Ghalia Indonesia)

This distance or gap is bridged through a warehousing process with certain techniques to prevent damage to the goods concerned. Transportation is closely related to warehousing or storage because both increase the benefits of goods. Transport allows goods to be moved from place to place other place so that it can be used where the item is not found.

Thus creating the benefits of space, in addition, storage or warehousing also allows goods to be stored until the time needed and this means giving time benefits. With a development transportation route, it will encourage the growth of other facilities which are of course economic value. The role of transportation in regional development, transportation generally focuses on the transportation network, location, structure, flow, and the significance and influence of the network on economic space related to regional development with the principle of dependence between networks and economic space as well as changes in accessibility. In this case, the better the transportation network, the better the accessibility, so that economic activity will also develop in an advanced society, as what we aspire to.

\section{Conclusion}

Transportation of goods in the context of implementing the sea highway, in order to guarantee the availability of goods and reduce price disparities for the community as well as to ensure the continuity of goods transportation services to underdeveloped, remote, outermost, and border areas. The marine transportation development policy, is directed at, among other things, increasing the role of the national shipping fleet for both 
domestic and export-import transportation by applying the cabotage principle; eliminating illegal levies at ports through improved coordination for all agencies related to the loading and unloading process and meeting international shipping standards issued by the International Maritime Organization, the International Association of Lighthouse Authorities and the implementation of International Ship and Port Security. Furthermore, restructuring the laws and regulations on shipping and implementing regulations, as well as institutions in the marine transportation sub-sector in order to create conditions that are able to attract private interest in the development of marine transportation infrastructure. Sea transportation is the lifeblood of increasing national development to smooth the flow of people, goods and information by sea as a means of achieving optimal allocation of economic resources. For this reason, sea transportation services must be sufficiently available and affordable for the people's purchasing power.

\section{References}

[1] Aminah, S. (2006). Transportasi Public dan Aksesibilitas Masyarakat Perkotaan. Surabaya: Universitas Airlangga.

[2] Haryadi, B. and Riyanto, B. (2007). City Density in a Sustainable Transportation Development Perspective. Journal of Civil Engineering and Planning, vol. 9, issue 2, pp. 89-97.

[3] Herdiyeni, Y., et al. (2014). Development of Mangrove Database for Biodiversity Informatics of IPB Biopharmaca. Jurnal IImu Pertanian Indonesia, vol. 19, issue 3, pp. 197-203.

[4] Hobbs, F. D. (2008). Perencanaan dan teknik lalu lintas. Yogyakarta: Gajah Mada University Press.

[5] Ilham, C. I. and Darwan, W. (2015). Keseimbangan antara Pendapatan dan Biaya Operasional Kapal Penyeberangan Lintas Jangkar-Kalianget. Jurnal Manajemen Transportasi \& Logistik, vol. 2, issue 1, pp. 26-35.

[6] Kadarisman, M., Gunawan, A. and Ismiyati, S. (2015). Policy Implementation of Land Transportation System and its Impact towards Social Welfare in Jakarta. Journal of Transportation \& Logistics Management, vol. 2, issue 1, pp. 62-68.

[7] Meyer, M \& Miller, M. (2007). Urban Transportation Planning. Ed. Msigwa. Singapura: McGraw-Hill International.

[8] Nasution, M. N. (2006). ManajemenTransportasi. Jakarta: Ghalia Indonesia.

[9] Mutholib, A. (2013). Kajian fasilitas keselamatan kapal pada lintas penyeberangan 35 ilir-muntok. Jurnal Transportasi, vol. 25, issue 5, pp. 140-146. 
[10] Nugroho, A. L. (2008). Layanan Konsumen dan Transportasi. Surakarta: Muhammadiyah University of Surakarta. 